\title{
Islam, Gender, and Social Change
}

Yvonne Yazbeck Haddad and John L. Esposito (eds.). New York and Oxford: Oxford University Press, 1997, $259 \mathrm{pp}$.

The anthology, Islam, Gender and Social Change, starts with an introduction by Professor John Esposito, one of the coeditors, and it continues with an overarching chapter "Islam and Gender: Dilemmas in the Changing Arab World" 
by the other coeditor, Professor Yvonne Yazbeck Haddad. The introduction gives a short survey of gender issues in Islamic history and it points out that reforms in women's issues have more often than not been a State rather than a grassroots concern. The strength of the introduction is that in contrast to many of the other articles in this volume, it takes into account not only the feminist point of view on gender but deals with the various views that exist in Muslim society.

Haddad's chapter introduces the first part of the anthology titled "Islam, Gender, and Social Change: A Reconstituted Tradition," which gives the reader a short survey of the modern challenges facing Arab society. She sees the main factors of change in the Arab world as the economic fluctuations of the 1970s and 1980s: labor migration, women's entrance into the labor market, State ideology and politics, the Islamic movement's role in society, United Nations' recommendations, and input from Western feminist movements. So far, so good; however, in her following comments, Haddad has a tendency to victimize Arab Muslim women, particularly the religious-oriented-a viewpoint which, as a researcher on the Muslim world, I cannot always agree with. This victimization is partly a result of how Muslim women are often described from an outsider's perspective, either from a Western or a secular Muslim point of view. Victimization of Muslim women is not only a feature in Haddad's article but also in many of the other articles in this book. Interestingly, even the few Muslim contributors do not have a particular Islamic outlook; rather, they are part of a Western research paradigm. The fact that Islamic-oriented Muslim women are generally defined within a frame of Western research traditions reinforces, on the one hand, attitudes of "we" and "them" and, on the other, the notion that these women are victims rather than women responsible for their own lives.

I would like to comment on two matters mentioned in Haddad's article. The first is her statement that the reason for the great number of unmarried women in Kuwait is that, due to their demand for high dowries, Kuwaiti men tend to marry Western women. Although I can agree with the criticism of high dowries, I believe that Haddad has failed to see that the problems of the large number of unmarried women not only in Kuwait but also in many other Muslim countries, are multifaceted. The marrying of Western women is one aspect of the problem; another is that there is often a large age difference between men and women. As women past a certain age (generally 25 years old) are regarded as "unmarriageable," men of the same age who want to get married must look for much younger girls, leaving a great number of women in every age group unmarried. The second point is that it would be helpful for the readers to know more about the scholars Haddad refers to and those who 
speak for the various Islamic points of view. For instance, who are Mustafa Hijazi and Mahmoud Sha'ban, and more importantly, what role do they play in the Islamic society?

The second article is written by Barbara Stowasser and deals with contemporary Qur'anic interpretations. She notes that in classic theology there was no major distinction between the "principal causes" and the "instrumental causes" of revelation. Thus, classical theology did not have "room for a concept of God as the first and absolute cause of revelation using the mental resources of his 'instruments,' the prophets, to cast His revelation into a specific human setting of place and time" (p. 31). Stowasser further states that despite the view of the Qur'an as absolute and timeless, the classical scholars investigated the chronological order of the revelations and looked at the verses in terms of the circumstances of their revelation (asbab al-nuzul). Contemporary scholars, she claims, avoid these matters because they are afraid of linking revelation too closely to their historical circumstances. I believe she is partly wrong in this assumption, as the trend among many prominent Islamist scholars, such as Muhammad al-Ghazzali and Yusuf al-Qaradawi, is the fiqh al-maqasid (jurisprudence of purpose). In this particular trend, it is the hermeneutic reading, the searching for the meaning or the reasons behind both Qur'anic verses and hadiths, which becomes important in their interpretations. An example is al-Ghazzali's view on female leadership where he makes use of hermeneutic methodology. Stowasser also looks into how the verse $(4: 34)$ about men's guardianship/responsibility over women has been interpreted by various contemporary scholars, beginning with Muhammad Abduh. She further refers to the interpretations made by Amina Wadud-Muhsin, Mahmoud Taha, and Nasr Hamid Abu Zay, showing how some of these scholars have followed extraIslamic models in their interpretations of the Qur'an.

The third article in Part One, deals with the realities of the life of Arab women. Nadia Hijab investigates into matters of law and identity in the Islamic framework. She begins her article by stating that "Today, Arab women are in the unenviable position of having to choose between rights and respect" (p. 46); then she continues by saying that the reason why women in the Arab world have not enjoyed equal rights to that of men is that the debate on women's role was conducted within the Islamic framework. I believe that her statement is due to a static understanding of Islam, and that she is not familiar with or chooses to disregard the more recent Islamic debate which is referred to in some of the other chapters.

Part Two of the anthology gives various case studies from the Muslim world. The first study is written by Afsaneh Najmabadi, and points at how Iranian women actively try to change traditional views on gender issues by rereading 
and reinterpreting the Islamic texts. It is interesting to note how the author talks several times about the traditional understanding of Isalm in terms of "misogyny." This clearly reflects her own position rather than the objects of her research, who, although modern in outlook, still keep their debate within an Islamic framework. What is also extremely interesting in her article, is how Shi'a women seem to have a stronger position in the Islamic contemporary debate than Sunni women do. It is even mentioned in a footnote that a woman named Fatimah Amin (d. 1983) acquired the status of mujtahid.

Mervat F. Hatem discusses the secularist and Islamist discourses on modernity in Egypt. Defining the difference between the two groups, she says: "While the secularist wants to localize cultural difference in the home/spiritual/inner domains, the Islamist wants to extend the reach to the definition of the roles that men and women play in the public/material/outer arenas" (p. 86). She also discusses how the religious experience of the vision of the Virgin Mary highlighted important concepts in Egyptian society. Seemingly, Hatem is not very clear about the Islamist discourse. For instance, she sees Shaykh alSha'rawi as an Islamist and puts him in the same category as the Muslim Brotherhood. When she discusses some of his ideas, she fails to see that his views are traditional rather than Islamist; consequently, her analysis suffers. Furthermore, Hatem tends to be instrumental in her analysis as she claims that some Islamists began a "conscious use" of the institution of the family in order to redefine the private and public roles of men and women (p. 92). Yet, what evidence does she have that this is a "conscious use" rather than an "unconscious use"? The fact that she later speaks in terms of Islamist "strategies," further reinforces her instrumental attitude — an attitude that can also be found in other articles of the anthology.

Laurie A. Brand's case study on Jordan is substantial in that she presents various views. In her discussion on Honor Crimes, however, and more particularly in her analysis on why the amount of blood money for a woman killed in a nonhonor crime is four to eight times that of a man, she fails to examine the value of a woman. Sadly, she only mentions the traditional agruments, such as the "presumed weakness" of women, the fact that the families bear responsibility for women's actions, and women's worth solely as birth-givers.

Although Anita M. Weiss, in her article on Pakistan, does not clearly distinguish between the traditional understanding of Islam and the modern Islamist one, she has managed to capture the Pakistani women's situation as multilayered. She mentions, for instance, that women in paid work are not necessarily more emancipated than housewives - an interesting observation at a time when the opposite notion prevails and has become an overarching paradigm within Western research. 
This is followed by three chapters that deal with the position of women in the Gulf States of Oman, Bahrain and Kuwait. Of these, the case study on Bahrain is the most interesting as it was one of the few chapters that let Islamist women advocate their ideas on an equal footing with the secularists. May Sekaly also made a distinction between the positions of the Shi'a and the Sunni women in Bahrain, and thus clarified some problems that exist in such societies and that, far too often, tend to be forgotten in the context of the Muslim world.

Margot Badran's article, however, needs some remarks. Similar to some of the other authors, she does not take the Islamist women's point of view into consideration. Although it is understandable that it might be difficult to get these women to accept to be research objects due to their bad experiences with Western researchers, it would have been appropriate to mention why they are hardly mentioned in the article, as Muslim women are very active and have various organizations in Kuwait. Moreover, Badran also tends to look at Islamist activities in an instrumental manner, saying that wearing the "hijab is a political statement, announcing an Islamist sympathy" (p. 203). She seems to forget that wearing the headscraft is essentially a personal choice linked to religiousity and piety.

In her article, Badran also discusses female votes and the possibility for women to be elected to Parliament. But she does not mention the most problematic point, namely, that according to the Kuwaiti constitution, a person who is able to vote can also be elected. In fact, this is a dilemma for many Islamists, as, in principle, they tend to be pro-female vote, but-as Badran rightly points out-would also be against the fact that women could be elected to all political positions. Thus, according to the Islamists, there is a need for constitutional change, which is a difficult matter.

To read about Muslim women in the Philippines is interesting, as they often tend to be forgotten in academic studies on Muslims. Discussion is lacking, however, on the particular Philippine gender system, named by Wazir Jahan Karim as a "bilateral system," which seems to be a trademark for Southeast Asia. In contrast to this view, the author of the article, Vivienne Angeles, speaks about the Philippine system as a "patriarchal system" without problematizing the concept. As Southeast Asian female scholars have actually raised the question of gender in this geographical context as something quite different from other parts of the world, it is unfortunate that Angeles has not taken this discussion into consideration.

On the whole, I observed that various authors in the anthology tended to confuse the concept of Muslim female dress without exemplifying what is meant by the different terms used. Moreover in their analysis of this phenomenon, 
there is a tendency to examine the issues in an instrumental manner, particularly when dealing with the Islamist activities.

Some authors also tend to mix up concepts of Islamic law, such as the Shari'ah, jurisprudence (fiqh), and Personal Status Law in the various Muslim countries. Indeed, it was sometimes difficult to understand what some authors were referring to, as they tend to use the term "Shari'ah" in all occasions. Moreover, some authors tend to look at Islamic Law as a homogenous and static entity, thus disregarding the actual development in this field.

Finally, I would like to mention the importance of giving Islamically-oriented women an official voice. Indeed, whereas Muslim women in general have come to be heard even within Western research in the last two decades, the voices of Islamically-oriented women are still not presented in the Western intellectual debate. This may be because such women are reluctant to come forward, but in my view it has more to do with the fact that they are rarely asked to be part of multidisciplinary projects such as the present study. With the growing number of Islamically-oriented women who pursue postgraduate studies, there might be more opportunities for them to define themselves in the future, rather than being defined by others.

Anne Sofie Roald Associate Professor International Migration and Ethnic Relations Malmö University Sweden 